\title{
Total rewards and its effects on organisational commitment in higher education institutions
}

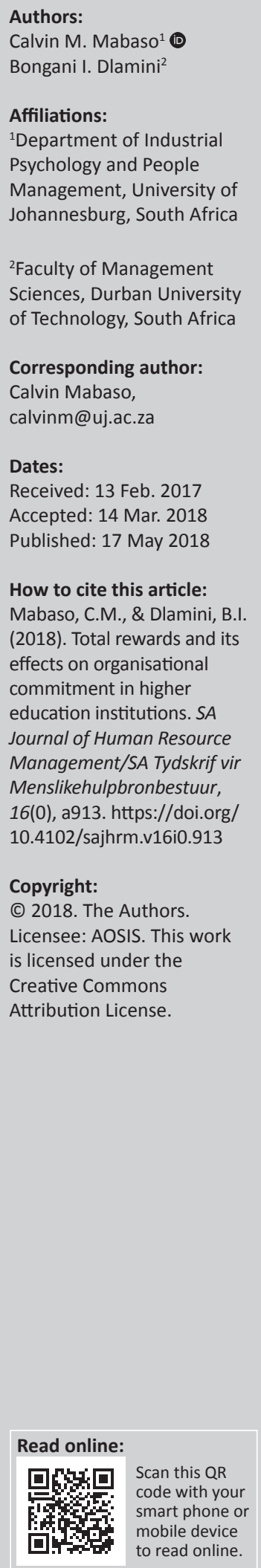

Orientation: Retaining staff with special endeavours within higher education institutions has become a top priority and crucial for any organisational productivity and competiveness. Attracting and retaining talent has remained a critical and complex issue for human capital management in organisations.

Research purpose: The purpose of this study was to investigate the impact of total rewards on organisational commitment measured by Total Rewards Scale and Organisational Commitment Questionnaire.

Motivation for the study: There is paucity in research on the impact of total rewards on organisational commitment. Commitment of academic staff is significant as higher education institutions are influential in the development of a country.

Research design, approach and method: This study employed the quantitative research method using a survey design. A semi-structured questionnaire was used to collect survey data. A sample of 279 academic staff, which was the total population of participants, was selected for this study.

Main findings: Results show a positive and significant correlation between elements of total rewards (performance management, 0.387; recognition, 0.335 ; talent development and career opportunities, 0.328; compensation, 0.231; benefits, 0.213; work-life balance, 0.024) and organisational commitment. A variance of $52.3 \%$ of total rewards explained organisational commitment. Performance management, compensation, benefits, recognition, talent development and career opportunities significantly predicted organisational commitment. However, work-life balance indicated a negative effect on organisational commitment.

Practical managerial implications: Findings of the study has implications to managers because they have to encourage and promote total rewards in order to enforce talent retention within higher education institutions for the benefit of both institutions and employees.

Contribution: The results are important to managers with great interest in talent retention and can be used as guideline to develop rewards strategy.

\section{Introduction}

\section{Key focus of the study}

Talent retention has been reported as a significant challenge for organisations operating in a competitive environment. Competing for employees with the required skillset and attracting and retaining employees with expertise has emerged as the biggest challenge for human capital managers. However, in higher education institutions, retaining of staff has become a priority. In addition, higher education is influential in the development of a country. It not only functions as a provider of knowledge but also as a pertinent sector for the nation's grown and societal wellbeing. Higher education institutions play a significant role in development of skills, which improves the economy; therefore, a high quality of staff is required. Higher education institutions are also considered as a centre of research, knowledge, change and excellence that is skilled in acquiring, generating and transferring knowledge to society. The study aims to investigate the relationship between total rewards and retention factors in relation to organisational commitment in higher education institutions.

\section{Background to the study}

Enhancing organisational commitment among academic staff is an essential element because it will eventually result in higher employee commitment, retention and improved performance. Therefore, 
identifying total rewards that influence organisational commitment in higher education institutions will aid the sector to foster organisational commitment, while maintaining high satisfaction and improved performance. Ihionkhan and Aigbomian (2014) attest that organisations are effective to the degree which it achieve its objectives through committed employees. In addition, Korir and Kepkebut (2016) state that committed employees have a sense of identification and belonging with an organisation. Dubihlela and Rundora (2014) affirm that an increase in global competition has forced businesses to ensure increased employee commitment in order to enable them to have a high level of excellence and competitiveness. Wasiu and Adelajo (2014) suggest that the importance of total rewards cannot be over emphasised. Wellrewarded employees feel that they are valued by the organisation. Anku-Tsede and Kutin (2013) state that rewarding employees is ideal in today's complex human resources market, which leads to continually changing settings in which organisations compete for survival. Obicci (2015) affirms that as employees are the engines of organisational vehicles, total rewards is the fuel through which organisations' stated objectives can be achieved. Ihionkhan and Aigbomian (2014) state that rewards management strategies can be used to increase employee commitment by creating a sense of belonging in the organisation. Increased levels of employee commitment can be achieved through effective rewards management strategies. Korir and Kipkebut (2016) advised organisations to take actions such that employee commitment can be obtained through total rewards management.

\section{Research purpose and objectives}

There is a limited research investigating specifically the relationship between total rewards and organisational commitment both locally and internationally. The main purpose of this study was to investigate the impact of total rewards on organisational commitment. The objectives of the study were to investigate the relationship between total rewards and organisational commitment. In addition, the following research questions were investigated:

- Research question 1: What is the relationship between total rewards and organisational commitment?

- Research question 2: Which total rewards elements influence organisational commitment significantly?

\section{Significance of the study}

Highly qualified and experienced employees of the academic institutions are continuously leaving in search of greener pastures and opportunities in other institutions and in the private sector. Those left behind may end up underperforming owing to low motivation because of insufficient reward strategies (Al-Jarradi, 2011). This study aims to assist the management of universities of technology to have the opportunity to be more aware about the influence of total rewards on organisational commitment. The findings of the research should also contribute to broader understanding in both public and private sectors on the significant role of total rewards in organisational commitment among employees. The study will benefit other institutions of higher learning, that is, traditional universities, universities of technology to understand total rewards that best drive organisational commitment.

\section{Literature review Organisational commitment}

Commitment in the workplace is a concept that has attracted a great deal of attention from scholars in many disciplines, including industrial psychology, organisational behaviour, management, business administration and public administration (Cohen, 2007). In addition, high interest in research, which is concerned with organisational commitment of employees, has been observed within the private sector, public sector and higher education sector (Dixit \& Bhati, 2012). Khan et al. (2014) state that organisational commitment is a link, association or bond of the employee with the institution, a psychosomatic state that distinguishes the individual association with the proposition for the decision to carry on attachment to the organisation. Lamba and Choudhary (2013) view organisational commitment as the individual psychological attachment to the organisation, and commitment represents something beyond loyalty to an organisation and involves an active relationship with the organisation such that individuals are willing to dedicate their talents in order to contribute to the organisation's well-being.

SamGnanakkan (2010) states that organisational commitment is a bi-dimensional concept that includes an attitudinal and a behavioural aspect. Committed employees have an active curiosity, a passion for learning, a willingness to challenge the status quo and an eagerness to experiment with new methods and strategies (Jafri, 2010). In addition, Cunningham (2012) states that an employee with a high level of organisational commitment wishes to maintain membership of the organisation, and this commitment differs from other types, such as occupational commitment. Welty, Burton and Wells (2014) reveal that employees with higher level of organisational commitment will be less likely to engage in job search behaviours as they would wish to stay and be associated with their organisation. In addition, employees with high level of commitment contributes positively to the organisation. In addition, organisational commitment encompasses an employee's belief in an organisation's goals and values, and reflects a desire by an employee to remain a member of the organisation and be loyal to it. Committed employees have an active curiosity, a passion for learning, a willingness to challenge the status quo and an eagerness to experiment with new methods and strategies (Jafri, 2010). Organisational commitment is a psychological state that impels an individual towards a course of action of relevance to one or more targets (Smith, Mitchell \& Mitchell, 2009). Therefore, organisational commitment results in positive attitudes to jobs and affects outcomes like employee's intention to leave, organisational citizenship behaviour, performance and job satisfaction (Neininger, LehmannWillenbrock, Kauffeld \& Henschel, 2010). However, human 
resources practices like total rewards influence the commitment of employees in both positive and negative manner (Döckel, 2003; Lumley, 2010). Hence, these practices are significant in retaining talent within organisations.

\section{Total rewards that retain talent}

In order to attract, retain and satisfy committed employees to the organisation, employers need appropriate total rewards (Obicci, 2015). Owing to competition for scarce skills, the attraction and retention of quality employees has emerged as the biggest challenge in human capital management (Terera \& Ngirande, 2014). Enhancing organisational commitment among employees is an essential element because that will result in higher employee commitment, enhancing retention, increasing their job satisfaction and improving performance (Omotayo, Pavithra, \& Adenike, 2014). In addition, bringing out the effects of total rewards will assist organisations foster commitment among employees. Research by Armstrong, Brown and Reilly (2010) reveals that competitive wages and benefits have repeatedly been listed as a means of attracting and retaining employees. Chelangat and Gachunga's (2016) study reveals that total rewards are considered as one of the tools for enhancing organisational commitment. Obicci (2015) attests that total rewards play a vital role in job satisfaction and enhances employee commitment with their respective organisations. Wages, therefore, influence the attraction and retention of the workforce. Organisations need to look for alternative methods of retaining key talent to ensure organisational success (Mabaso, 2016). Hence, total rewards can be used in order to enforce talent retention among academic staff in higher education institutions.

\section{Total rewards}

WorldatWork (2015) recommended a total rewards model with six essential elements, which are discussed in detail below. WorldatWork (2015) asserts that these elements of total rewards collectively define an organisation's strategy to attract, motivate, retain and engage employees.

\section{Compensation as element of total rewards}

Compensation is the reward that employees receive in exchange for performing organisational tasks (Omotayo, Pavithra \& Adenike, 2014). In addition, WorldatWork (2015) postulates that compensation refers to remuneration provided by the employer for services rendered by employees, which include skills, time and their efforts. WorldatWork (2015) affirms that compensation consists of both fixed and variable pay, and it is sometimes tied to performance. Martocchio (2013) states that compensation represents both intrinsic and extrinsic rewards employees receive for performing their jobs. Intrinsic compensation reflects employee's psychological mindsets that result from performing their jobs. Extrinsic compensation includes both monetary and non-monetary rewards (Martocchio, 2013). Total compensation is the total of all rewards provided to employees in return for their services' (Phonsanam, 2010:6). Ray and Ray (2011) observed that the main reason people work for is compensation. Rose (2014) confirms that compensation forms part of the elements of total rewards aiming to attract and retain talent in organisations.

\section{Fringe benefits as element of total rewards}

WorldatWork (2015) states that benefits comprise nonmonetary rewards to supplement financial compensation that employees receive. Martocchio (2013) states that fringe benefits include any variety of programmes that provide time off, employee services and protection programmes. According to Van der Westhuizen (2017), fringe benefits refer to indirect forms of compensation which are intended to attract, retain and motivate employees. Rose (2014) attests that fringe benefits consist of non-cash parts of the reward that are provided by the employer either to all employees or differentiated by level. Employee benefits consist of arrangements made by employers to enhance their employees' well-being. The benefits are provided in addition to pay and form important parts of the total rewards package (Armstrong, 2012). Benefit packages for employees are integral to the financial reward package, and for many organisations, the employer brand determines the type of benefits offered, which turn, support the messages to be delivered via the employer brand.

\section{Work-life balance as element of total rewards}

WorldatWork (2015) states that work-life programmes are intended and introduced as policies that enable employers to reach a better work-life balance. This factor includes the extent to which a specific job is interesting and challenging to an individual, the degree to which the job provides the opportunity for an individual to keep abreast of new things (WorldatWork, 2015). According to Mukhtar (2012), integrating and maintaining work-life balance into our lives is the current need. Rumpel and Medcof (2006) attest that usually the balance time spent at work and home is included in the work environment. Flexible working is one of the most important aspects for a balanced life (Hondor, 2014).

\section{Performance as element of total rewards}

Aguinis (2013) defines performance management as a continuous process of identifying, measuring and developing the performance of individuals, teams and aligning performance with the strategic goals of the organisation. In addition, Swanepoel et al. (2014) affirm that performance management is an action based on performance measures and reporting, which results in improvement in employee behaviour, motivation and work processes as well as promoting innovation. Performance management is viewed more broadly as a management tool that aims to improve the performance of an organisation (Goh, 2012).

\section{Recognition as element of total rewards}

Rose (2014) states that recognition refers to a process of acknowledging or giving special attention to a high level of 
accomplishment or performance, such as customer care or support to colleagues, which is not dependent on achievement against a given target or objective. Greene (2011) attests that recognition can be used in lieu of financial awards, as particularly it could be argued that people used time that theoretically should have been spent on other organisational businesses and that the salary provided compensation. Abu Bakar, Mohamad and Sharmeela-Banu (2015) posit that recognition is the demonstration of appreciation for a level of performance, an achievement or a contribution to an objective. It can be confidential or public, causal or formal and it is always in addition to pay. The link between recognition, teamwork and job satisfaction is an important occurrence to take note of as it indicates that dimensions, which constitute job satisfaction, do not necessarily act alone in determining the job satisfaction of employees. The lack of recognition would not lead to job dissatisfaction, but employees are unlikely to be unmotivated (Smerek \& Peterson, 2007).

\section{Talent development and career opportunities as element of total rewards}

It is a set of learning experiences intended to improve employees' functional expertise and capabilities. It motivates employees to complete their tasks quickly which in turn improves their productivity (Hondor, 2014). WorldatWork (2015) states that career opportunities involve a strategy for employees to develop their career goals, which may include advancement into a more responsible position in an organisation. Greene (2011) affirms that the investment in training and development is to increase capacity among employees which will enable career opportunities in the workplace. Martocchio (2013) concurs that talent development will enable employees to maintain their focus and assume greater responsibilities and advance in the organisation hierarchy.

\section{Research hypothesis}

Based on the above literature, the following hypothesis was developed:

- Hypothesis $1\left(\mathbf{H}_{1}\right)$ : There is a positive relationship between total rewards and organisational commitment.

\section{Research design}

\section{Research approach}

In the present study, a quantitative research design was employed using the survey questionnaire. The aim of the quantitative research is to describe patterns, trends and relationships in numerical data (Lochmiller \& Lester, 2017). The main reason for choosing this method was that variables used in the present study could be easily measured quantitatively. In addition, the quantitative research method is concerned with the facts or responses of participants (Creswell, 2014). The most common characteristic of quantitative studies is generalisability of the results. Generalisability is the assumption that data from a sample represent the larger population from which the sample is drawn. Lochmiller and Lester (2017) affirm that in the quantitative research method, the research assumes that the results represent the broader population on some measures.

\section{Research method}

\section{Research participants}

This study was conducted in the higher education sector of South Africa. The target population in the present study comprised 279 (University of Technology A = 79; University of Technology B = 200) academic staff from two universities of technology (UOT) in Gauteng and Free State (from level of lecturers, senior lecturers, head of departments and professors). Of the 279 participants, 225 returned the questionnaires to the researcher. However, upon scrutiny it was discovered that 23 respondents did not answer the majority of the questions. These questionnaires were therefore discarded completely. A response rate of $72.4 \%$ was achieved. Therefore, questionnaires returned for analysis equated to $n=202$ questionnaires which was appropriate to be used on the study. An analysis of the demographic profile of respondents (Table 1) has been distributed to as per response from both universities of technology. In addition, Table 1 reveals that $50.5 \%(n=102)$ of the respondents were female, whereas $49.5 \%(n=100)$ were male. After collapsing the respondents' ages, it emerged that the largest group of respondents $(43.6 \% ; n=88)$ were aged between 30 and 45 years. In addition, $38.1 \%(n=77)$ of the respondents were in possession of a master's degree. In terms of racial group, Africans $(68.8 \% ; n=139)$ constituted the highest number. With regard to the position occupied, the largest group of

TABLE 1: Demographic profile of respondents $(N=202)$.

\begin{tabular}{|c|c|c|c|c|c|}
\hline Variable & Categories & UOT A & บOT B & $N$ & $\%$ \\
\hline \multirow[t]{2}{*}{ Gender } & Male & 34 & 66 & 100 & 49.5 \\
\hline & Female & 45 & 57 & 102 & 50.5 \\
\hline \multirow[t]{4}{*}{ Age } & $18-29$ & 18 & 32 & 49 & 24.3 \\
\hline & $30-45$ & 22 & 66 & 88 & 43.6 \\
\hline & $46-64$ & 37 & 24 & 61 & 30.2 \\
\hline & $>65$ & 2 & 2 & 4 & 1.9 \\
\hline \multirow[t]{4}{*}{ Race } & African & 41 & 108 & 139 & 68.8 \\
\hline & Indian & 3 & 12 & 14 & 6.9 \\
\hline & White & 29 & 12 & 41 & 20.3 \\
\hline & Mixed race & 6 & 2 & 8 & 4.0 \\
\hline \multirow[t]{4}{*}{ Tenure } & 0-1 year & 18 & 4 & 22 & 10.9 \\
\hline & $1-4$ years & 13 & 37 & 50 & 24.8 \\
\hline & $5-7$ years & 13 & 55 & 68 & 33.7 \\
\hline & $7-15$ years & 35 & 27 & 62 & 30.7 \\
\hline \multirow[t]{6}{*}{ Qualification } & Honours degree & 7 & 21 & 33 & 16.3 \\
\hline & Master's degree & 36 & 33 & 77 & 38.1 \\
\hline & $\mathrm{PhD}$ & 7 & 10 & 17 & 8.4 \\
\hline & B.Tech & 17 & 20 & 35 & 17.3 \\
\hline & M.Tech & 5 & 28 & 33 & 16.3 \\
\hline & D.Tech & 7 & 0 & 7 & 3.5 \\
\hline \multirow[t]{5}{*}{ Rank } & Lecturer & 70 & 111 & 181 & 89.6 \\
\hline & Senior lecturer & 5 & 9 & 14 & 6.9 \\
\hline & Associate professor & 0 & 1 & 1 & 0.5 \\
\hline & Professor & 2 & 0 & 2 & 1.0 \\
\hline & Head of department & 0 & 4 & 4 & 2.0 \\
\hline
\end{tabular}

UOT, universities of technology. 
respondents $(89.6 \% ; n=181)$ were lecturers, followed by senior lecturers $(6.9 \% ; n=14)$, with associate professors $(0.5 \% ; n=1)$ being the least in number.

\section{Measuring instrument}

A structured questionnaire was designed to gather information from participants. The current study used two measuring instruments; that is, 'Total Rewards Questionnaire' and 'Organisational Commitment Questionnaire'. Total Rewards Questionnaire was adopted from WorldatWork Rewards (2015), while Meyer and Allen (1997) developed Organisational Commitment Questionnaire. These two questionnaires were administered to the selected respondents. Both these instruments are based on the five-point Likert scale. The respondents were asked to indicate the extent of their agreement or disagreement with the statements on a scale of $1-5$, where 1 would mean that they strongly disagreed and 5 would mean that they strongly agreed with the statement provided.

\section{Ethical consideration and research procedure}

Permission to conduct the research was obtained from the participating universities of technology. Research participants were requested to participate in the study voluntarily by completing questionnaires. A covering letter accompanied each questionnaire stating the purpose of the research and guaranteeing protection of their identity as this was an anonymous survey. A total of 279 questionnaires were distributed to all academic staff using a personal method of data collection. To ensure confidentiality, questionnaires were to be returned in enclosed envelopes provided during distribution.

\section{Reliability}

Maree (2017) states that reliability refers to the consistency or dependability of a measuring instrument. A measuring instrument that is reliable will produce the same results if a variable is repeatedly measured under almost identical circumstances. The Cronbach's alpha was calculated for each construct to determine the scale reliability. Thurston and McNall (2010) reported that Cronbach's alpha should range from the lowest of 0.68 and to the highest of 0.93 . The Total Rewards Scale results (0.822).

\section{Data analysis}

Data were analysed with the aid of the Statistical Package for the Social Sciences (SPSS version 24). Descriptive statistics was used to analyse biographical information. Initially, demographic data of the subjects, frequencies and the scores of the overall work-related factors as well as measures of central tendency were established. Pearson correlation analysis and linear regression were computed on all the variables.

\section{Ethical considerations}

The study accompanied a letter explaining the ethical considerations involved, notably that participating in the study was a voluntary exercise and that the respondents could withdraw from the study at any point.

\section{Results}

The following results will be presented: correlation and regression analysis.

\section{Research question 1 and hypothesis 1}

In order to answer the first research question to determine the relationship between total rewards and organisational commitment and hypothesis 1, correlation analysis was performed to test the strength and directions of the relationship between variables as illustrated in Table 2 .

Pearson correlations allowed the researcher to identify the direction and strength of the relationship between each variable. As illustrated in Table 2, significant and positive relationships were observed between variables of total rewards and organisational commitment. The results of the correlation indicate a positive and significant relationship between the elements of total rewards and organisational commitment (performance management, 0.387; recognition, 0.335; talent development and career opportunities, 0.328 ; compensation, 0.231; benefits, 0.213; work-life balance, 0.024). The results in Table 2 reveal a positive and significant relationship between organisational commitment and four elements of total rewards (performance management, recognition, talent development and career opportunities, compensation and benefits). No significant relationship between work-life balance and organisational commitment was observed. This reveals that academic employees in higher education institutions will be committed if these elements of total rewards are provided by the employer. Based on the results in Table 2, the relationship between total rewards and organisational commitment is positive and the

TABLE 2: Significant Pearson correlations.

\begin{tabular}{|c|c|c|c|c|c|c|c|}
\hline Variables & 1 & 2 & 3 & 4 & 5 & 6 & 7 \\
\hline Compensation & 1.000 & - & - & - & - & - & - \\
\hline Benefits & 0.087 & 1 & - & - & - & - & - \\
\hline Work-life balance & 0.045 & $-0.172 *$ & 1.000 & - & - & - & - \\
\hline $\begin{array}{l}\text { Performance } \\
\text { management }\end{array}$ & $0.285^{* *}$ & -0.011 & $0.307 * *$ & 1.000 & - & - & - \\
\hline Recognition & $0.184 * *$ & 0.073 & 0.067 & $0.335 * *$ & 1.000 & - & - \\
\hline $\begin{array}{l}\text { Talent development } \\
\text { and career } \\
\text { opportunities }\end{array}$ & 0.121 & 0.088 & 0.077 & $0.291 * *$ & $0.335 * *$ & 1.000 & - \\
\hline $\begin{array}{l}\text { Organisational } \\
\text { commitment }\end{array}$ & $0.231 * *$ & $0.213 * *$ & 0.024 & $0.387 * *$ & $0.328 * *$ & $0.404 * *$ & 1.000 \\
\hline
\end{tabular}

*, Correlation is significant at the 0.05 level (2-tailed); $* *$, Correlation is significant at the 0.01 level (2-tailed). 
TABLE 3: Regression and model summary and analysis of variance results.

\begin{tabular}{lccccc}
\hline Total rewards & $\boldsymbol{R}$ & $\boldsymbol{R}^{2}$ & Adjusted $\boldsymbol{R}^{\mathbf{2}}$ & $\boldsymbol{F}$ & $\boldsymbol{p}$ \\
\hline Model 1 & $0.503^{\mathrm{a}}$ & 0.523 & 0.516 & 114.316 & 0.000 \\
\hline
\end{tabular}

TABLE 4: Contribution of independent variables for predicting organisational commitment.

\begin{tabular}{lccc}
\hline Independent variables & $\begin{array}{c}\text { Standardised beta } \\
\text { coefficients }\end{array}$ & $\boldsymbol{T}$ & $\boldsymbol{I}$ \\
\hline Compensation & 0.103 & 1.645 & 0.101 \\
Benefits & 0.178 & 2.926 & $0.004^{*}$ \\
Work-life balance & -0.064 & -1.006 & 0.316 \\
Performance management & 0.318 & 4.709 & $0.000^{*}$ \\
Recognition & 0.160 & 1.440 & 0.151 \\
$\begin{array}{l}\text { Talent development and } \\
\text { career opportunities }\end{array}$ & 0.213 & 3.406 & $0.001^{*}$ \\
\hline
\end{tabular}

*, Statistically significant at $p<0.05$

hypothesis is accepted that total rewards is positively related to organisational commitment. Pallant (2010) explains that the strength of the association between variables depends on the size (whether positive or negative) of the correlation value. A value ranging from 0.10 to 0.29 denotes a small relationship, values between 0.30 and 0.49 represent a medium relationship and a value of $0.5-1.0$ depicts a strong relationship between the variables.

Multivariate regression analysis was undertaken to determine the effects of total rewards on organisational commitment among academic staff. In Table 3, the regression model summary and ANOVA results are reported. Regression analysis is a statistical technique that focuses on investigating and modelling the relationship between variables (Montgomery, Peck \& Vining, 2012). Regression analysis aids to measure the relative strength of an independent variable on a dependent variable.

As illustrated in Table 3, the significant $F$-ratio infers that the regression model predicts effects of total rewards. The value of $R^{2}$ indicates that the model tested is significant, that is, the value of $R^{2}$ is 0.523 , which means that there is $52.3 \%$ relationship between independent variable (total rewards) and dependent variable (organisational commitment). Cohen, Manion and Morrison (2011) suggested that $R^{2}>0.5$ indicates a strong model fit. Therefore, these results confirm that total rewards have a greater impact on organisational commitment.

Additionally, regression was conducted as to evaluate the independent variables prediction of organisational commitment and is delineated in Table 4.

These results outlined in Table 4 suggest that compensation ( $\beta=0.103)$, benefits $(\beta=0.178)$, performance management $(\beta=0.318)$, recognition $(\beta=0.160)$, talent development and career opportunities $(\beta=0.213)$ all have a statistically positive effect on organisational commitment. However, work-life balance $(\beta=-0.64)$ has a negative effect on organisational commitment. This means that work-life balance does not influence organisational commitment. In terms of the largest beta coefficients recorded, performance management and talent development and career opportunities seem to make the strongest contribution to explaining organisational commitment. The $t$-values of the independent variables are greater than 0.107. Ndungu (2017) states that values greater than 0.107 indicate a strong impact of the predicting quality of the coefficient.

\section{Discussion}

The purpose of this study was to examine the impact of total rewards on organisational commitment among academic staff in higher education institutions. This was important as there is paucity on the studies that deals with impact of total rewards in higher education institutions. The findings in the current study reveal that performance management has a significant and positive relationship with organisational commitment. This finding is in line with the results of Abrokwah and Ge (2017) and Asamany and Shaorong (2018). In addition, the findings of the present study demonstrated the relationship between total rewards and organisational commitment. Moreover, these findings are in line with findings of Obicci (2015); Eslami and Gharakhani (2012) reported strong association between job-related factors, which include compensation and organisational commitment. Work- and job-related features are powerfully related to organisational commitment (Al-Kahtani, 2012). Saeed et al. (2013) reported that compensation and job characteristics have a weak positive and significant impact on organisational commitment, but career development has insignificant impact on organisational commitment. Saqib, Abrar, Sabir, Bashir and Baig's (2015) study indicated that there is a relationship between the tangible, intangible rewards and organisational commitment. The empirical results supported the relationship between the tangible rewards and organisational commitment. These findings showed that rewards had a positive and significant impact on the organisational commitment, which are in line with the literature. The Ndungu (2017) study reported that recognition and career opportunities are associated with increased performance among employees, which will enable them to be committed to their employer. In addition, Ndungu (2017) attests that if employees are not satisfied with salaries and fringe benefits, they will have no choice other than to look for alternative organisations that will be providing better salaries and benefits. Cao, Chen and Song's (2013) study confirms that total rewards elements (compensation, benefits, work-life balance, performance management and recognition, talent development and career opportunities) can be used to reduce turnover intention among employees. If total rewards are implemented fairly, employees can be committed to the organisation. Performance management specialists over the years have learnt that for organisations to achieve outstanding results in the competitive environment, practice of performance management is required. Thus, effective performance management system will aid organisations to improve organisational commitment and talent retention. Greene (2011) concurs that rewarding performance equitably and effectively is critical for organisations that aim to enforce organisational commitment.

Chelangat and Gachunga (2016) affirm that total reward practices play a pivotal role in organisational commitment 
among employees. Total rewards change the way employees think about work, and attracts and retains high-performing employees. If organisations want to increase organisational commitment, they should review their reward management practices (Chelangat \& Gachunga, 2016). The current study is in line with the study of Cheah, Chong, Yeo and Pee (2016) which revealed that talent development and compensation significantly affect organisational commitment. Korir and Kipkebut (2016) reported a positive significant relationship between total rewards and organisational commitment. The study suggested that financial rewards have an effect on organisational commitment and suggested that universities should carry out salary revisions in order to develop a reward management structure that is externally competitive, internally fair and consistent with the current acceptable international rates. Research by Zaitouni, Sawalha and Sharif (2011) suggests that employees who are provided with benefits, such as increased salary, bonuses and promotion, develop strong feelings of loyalty to the organisation. Perceptions of fair rewards and justice lead to higher levels of satisfaction and long-term commitment too.

\section{Implications for managers and recommendations}

The findings of this study, which support previous studies in the area, have significant implications as it further confirmed that total rewards impact organisational commitment. These results have implications to managers because they have to encourage and promote total rewards in order to enforce talent retention within higher education institutions for the benefit of both institutions and employees. Moreover, higher education institutions need to create an environment in which employees can work effectively. Recognising and rewarding employees effectively will further increase commitment among academics. Lastly, performance management cannot be overlooked as it has been done previously, this study reveal a great influence in ensuring organisational commitment and talent retention.

\section{Conclusion}

For higher education institutions to attract, retain and motivate talent, sound rewards strategy needs to be formulated. Total rewards can be used to retain talent. In addition, performance management should be improved as it influences organisational commitment among academic staff. Results of the present study can be used to craft a rewards strategy aimed at retaining high-performing resources.

\section{Acknowledgements}

The authors would like to thank academic staff who took part in the study.

\section{Competing interests}

The authors declare that they have no financial or personal relationships that may have inappropriately influenced them in writing this article.

\section{Authors' contributions}

The study was conducted by C.M.M. as part of the Doctor of Philosophy in Management Sciences: Human Resources Management research project and was responsible for preparing the manuscript. B.I.D. was the promoter and edited the article for publication.

\section{References}

Abu Bakar, J.A., Mohamad, Z.Z., \& Sharmeela-Banu, S.A. (2015). Factors affecting female lecturer retention in private higher institution in Perak. International Journal of Academic Research in Business and Social Sciences, 5(1), 17-25.

Abrokwah, E., \& Ge, Y. (2017). Mediating role of work motivation: Does organizational commitment impact on Non-Governmental Organizations (NGOs) performances? Transylvanian Review Journal, XXV(17), 15-38.

Aguinis, H. (2013). Performance management (3rd ed.). Upper Saddle River, NJ: Pearson Prentice Hall.

Al-Jarradi, K.S. (2011). An investigation into the effectiveness of the reward system in the government sector in the Sultanate of Oman and the potential for introducing a total reward strategy. (Unpublished PhD thesis). University of Manchester, Manchester.

Al-Kahtani, S.N. (2012). An exploratory study of organisational commitment, demographic variables and job \& work related variables among employees in Kingdom of Saudi Arabia. Online International Interdisciplinary Research Journal, 3, 1-13.

Anku-Tsede, A.O., \& Kitui, E. (2013). Total rewards concept: A key motivational tool for corporate Ghana. Business and Economic Research, 3(2), 173-182. https://doi. org/10.5296/ber.v3i2.4291

Armstrong, M. (2012). Armstrong's handbook of reward management practice. London: Kogan Page.

Armstrong, M., Brown, D., \& Reilly, P. (2010). Evidence-based reward management: Creating measurable business impact from your pay and reward practices. London: Kogan Page.

Asamany, A., \& Shaorong, S. (2018). The ripple effects of performance management on employees' perceptions and affective commitment among small and medium scale enterprises (SMEs). International Journal of Business Administration, 9(1), 55-63. https://doi.org/10.5430/ijba.v9n1p55

Cao, Z., Chen, J., \& Song, Y. (2013). Does total rewards reduce the core employees turnover intention? International Journal of Business and Management, 8(20), 62-75. https://doi.org/10.5539/ijbm.v8n20p62

Cheah, C.S., Chong, W.V.S., Yeo, S.F., \& Pee, K.W. (2016). An empirical study on factors affecting organisational commitment among Generation X. Procedia-Social and Behavioral Sciences, 219, 167-174. https://doi.org/10.1016/j.sbspro.2016.05.002

Chelangat, Z., \& Gachunga, H. (2016). Effect of reward management practices on organisational commitment in state corporations in Kenya: A case study of Kefr. The Strategic Journal of Business and Change Management, 3(3), 325-346.

Cohen, A. (2007). Dynamics between occupational and organisational commitment in the context of flexible labor markets: A review of literature and suggestions for a future research agenda. Bremen: Institut Technik und Bildung, UniversitŠt Bremen.

Cohen, L., Manion, L., \& Morrison, K. (2011). Research methods in education. London: Routledge.

Creswell, J. (2014). Research design qualitative, quantitative and mixed methods approaches (4th ed.). Thousand Oaks, CA: Sage.

Cunningham, G.B. (2012). The relationships among commitment to change, coping with change, and turnover intentions. European Journal of Work and Organisational Psychology, 15(1), 29-45. https://doi.org/10.1080/1359432 0500418766

Dixit, V., \& Bhati, M. (2012). A study about employee commitment and its impact on sustained productivity in Indian auto-component industry. European Journal of Business and Social Sciences, 1(6), 34-51.

Döckel, A. (2003). The effect of retention factors on organisational commitment: An investigation of high technology employees. (Unpublished master's thesis). University of Pretoria, South Africa.

Dubihlela, J., \& Rundora, R. (2014). Employee training, managerial commitment and the implementation of activity based costing; Impact on performance of SMEs. The International Business \& Economics Research Journal, 13(1), 27-42.

Eslami, J., \& Gharakhani, D. (2012).Organisational commitment and job satisfaction. ARPN Journal of Science and Technology, 2(2), 85-91.

Goh, S.C. (2012). Making performance measurement systems more effective in public sector organizations. Measuring Business Excellence, 16(1), 31-42. https://doi. org/10.1108/13683041211204653

Greene, R.J. (2011). Rewarding performance: Guiding principles; custom strategies. London, United Kingdom: Taylor \& Francis Ltd.

Hondor, E.S. (2014). Total rewards model in Romanian companies. Cross-Cultural Management Journal, 16(30), 313-319.

Ihionkhan, P.A., \& Aigbomian, E.E. (2014). The influence of human resource management practices on organisational commitment: A study of manufacturing organisations in Nigeria. Indian Journal of Commerce \& Management Studies, $5(1), 18-28$ 
Jafri, M.H. (2010). Organisational commitment and employee's innovative behaviour Journal of Management Research, 10(1), 62-68.

Khan, M.S., Khan, I., Kundi, G.M., Khan, S., Nawaz, A., Khan, F., \& Yar, N.B. (2014). The impact of job satisfaction and organisational commitment on the Intention to leave among the Academicians. International Journal of Academic Research in Business and Social Sciences, 4(2), 114-131.

Korir, I., \& Kepkebut, D. (2016). The effect of reward management on employees commitment in the Universities of Nakuru Country - Kenya. Journal of Human Resources Management, 4(4), 37-48. https://doi.org/10.11648/j.jhrm. 20160404.12

Lamba, S., \& Choudhary, N. (2013). Impact of HRM practices on organisational commitment of employees. International Journal of Advancements in Research and Technology, 2(4), 407-423.

Lochmiller, C.R., \& Lester, J.N. (2017). An introduction to educational research connecting methods to practice (1st ed.). Los Angeles, CA: Sage.

Lumley, E. (2010). The relationship between career anchors, job satisfaction and organisational commitment. (Unpublished master's dissertation). University of South Africa, Pretoria.

Mabaso, C. (2016). The influence of rewards on talent attraction and retention at a further education and training college in Gauteng. (Unpublished masters further education and training college in Gauteng.
dissertation). Vaal University of Technology, South Africa.

Maree, K. (2017). First steps in research. Pretoria, South Africa: Van Schaik Publishers.

Martocchio, J.J. (2013). Strategic compensation: A human resource management approach (7th ed.). Upper Saddle River, NJ: Pearson.

Meyer, J., \& Allen, N. (1997). Commitment in the workplace: Theory, research, and application. Thousand Oaks, CA: Sage.

Montgomery, D.C., Peck, E.A., \& Vining, G. (2012). Introduction to linear regression analysis (5th ed.). New York: John Wiley \& Sons.

Mukhtar, F. (2012). Work life balance and job satisfaction among faculty at lowa State University. (Unpublished doctoral dissertation). lowa State University, Ames: IA.

Ndungu, D.N. (2017). The effects of rewards and recognition on employee performance in public educational institutions: A case of Kenyatta University, Kenya. Global Journal of Management and Business Research: Administration and Management, 17(1), 43-68.

Neininger, A., Lehmann-Willenbrock, N., Kauffeld, S., \& Henschel, A. (2010). Effects of team and organisational commitment - A longitudinal study. Journal of Vocational Behavior, 76(3), 567-579. https://doi.org/10.1016/j.jvb.2010.01.009

Obicci, P.A. (2015). Influence of total rewards on employee satisfaction and commitment in government organization. International Journal of Research in Management, Science and Technology, 3(1), 47-56.

Omotayo, O.A., Pavithra, S., \& Adenike, A.A., (2014). Compensation management and organisational commitment in developing economies: Indian perspective. International Journal of Research in Management, Social Sciences \& Technology, $8(8), 1-15$.

Pallant, J. (2010). SPSS survival manual: A step-by-step guide to data analysis using the SPSS program (4th ed.). New York: McGraw Hill.

Phonsanam, S.T. (2010). Total compensation practices and their relationship to hospitality employee retention. (Unpublished master of science dissertation). University of Nevada, Las Vegas.
Ray, S., \& Ray, I.A. (2011). Human resource management practices and its effect on employees' job satisfaction: A study on selected small and medium sized iron and steel firms in India. Public Policy and Administration Research, 1(1), 22-31.

Rose, M. (2014). Reward management. London: Kogan Page.

Rumpel, S., \& Medcof, J.W. (2006). Total rewards: Good fit for tech workers. Research Technology Management, 49(5): 27-35.

Saeed, R., Lodhi, R.N., Iqbal, A., Nayyab, H.H., Mussawar, S., \& Yaseen, S. (2013). Factors influencing job satisfaction of employees in telecom sector of Pakistan. Middle-East Journal of Scientific Research, 16(11), 1476-1482.

SamGnanakkan, S. (2010). Mediating role of organisational commitment on HR practices and turnover intention among ICT professionals. Journal of Management Research, 10(1), 39-61.

Saqib, S., Abrar, M., Sabir, H.M., Bashir, M. \& Baig, S.A. (2015). Impact of tangible and intangible rewards on organisational commitment: Evidence from the textile sector of Pakistan. American Journal of Industrial and Business Management, 5(3), 138-147. https://doi.org/10.4236/ajibm.2015.53015

Smerek, R.E. \& Peterson, M. (2007). Examining Herzberg's theory: Improving job satisfaction among non-academic employees at a university. Research in Higher Education, 48(2), 229-250.

Smith, J.B., Mitchell, J.R., \&Mitchell, R.K. (2009). Entrepreneurial scripts and the new transaction commitment mindset: Extending the expert information processing theory approach to entrepreneurial cognition research. Entrepreneurship Theory and Practice, 33(3), 815-844. https://doi.org/10.1111/j.1540-6520.2009.00328.x

Swanepoel, B.J., Erasmus, B.J., Schenk, H.W., \& Tshilongamulenzhe, T. (2014). South African human resource management: Theory and practice (4th ed.). Cape Town, South Africa: Juta.

Terera, S.R., \& Ngirande, H. (2014). The impact of rewards on job satisfaction and employee retention. Mediterranean Journal of Social Sciences, 5(1), 481-487. https://doi.org/10.5901/mjss.2014.v5n1p481

Thurston, P.W. Jr., \& McNall, L. (2010). Justice perceptions of performance appraisal practices. Journal of Management Psychology, 25(3), 201-228. https://doi. org/10.1108/02683941011023712

Van der Westhuizen, E. (2017). Human Resource Management in Government: A South African perspective of theories, politics and processes (1st ed.). Cape Town, South Africa: Juta \& Co.

Wasiu, D.O., \& Adebajo, A.A. (2014). Reward systems and employee performance in Lagos state (a study of selected public secondary schools). Kuwait Chapter of Arabian Journal of Business and Management Review, 3(8), 14-23. https://doi.org/10.12816/0018303

Welty, J., Burton, L., \& Wells, J.E. (2014). Examining the influence of transformational leadership, leader-member exchange, organisational commitment, job embeddedness and job search on turnover intentions of Division I senior administrators. Leadership \& and job search on turnover intentions of Division I senior administrators. Leadership \&
Organisational Development Journal, 35(8), 740-755. https://doi.org/10.1108/LODJ10-2012-0128

WorldatWork. (2015). Total rewards model a framework for strategies to attract, motivate and retain employees. Retrieved from https://www.worldatwork.org/ waw/adimLink?id $=28330$

Zaitouni, M., Sawalha, N.N., \& Sharif, A. (2011). The impact of human resource management practices on organisational commitment in the banking sector in Kuwait. International Journal Business and Management, 6(6), 108-123. https:// doi.org/10.5539/ijbm.v6n6p108 